\title{
Pengaruh Pelatihan Non Teknis terhadap Kinerja Penyuluh Pertanian BP4K di Kabupaten Bungo Provinsi Jambi
}

\author{
Influence of Non Technical Training to the Agricultural Extension Workers Performance in BP4K \\ Bungo Jambi Province
}

\author{
Ike Wirdani Putri ${ }^{1}$, Anna Fatchiya ${ }^{2}$, Siti Amanah² \\ ${ }^{1}$ Alumni Universitas Andalas, Padang
}

${ }^{2}$ Departemen Sains Komunikasi dan Pengembangan Masyarakat, Fakultas Ekologi Manusia, Institut Pertanian Bogor, Bogor

\begin{abstract}
To support performance of extension worker BP4K Bungo had conduct a non-technical training. This study aims to: analyze the suitability of the training to agricultural extension worker and analyze the performance of agricultural extension workers after participating in non-technical training. The research is carried out using 100 agricultural extension worker by census and analysis of data using descriptive statistics and inferential statistics (multiple linear regresion). The results show that: 1) the frequency of training and motivation of the workers positively affect the performance of the extension workers; 2) Method of training and infrastructure affect the effectiveness of the training. The more innovative method used for training supported by better infrastructure will support better performance of the extension workers; 3) the appropriateness of the course materials and better learning plan will improve the training performance; 4) support from extension organization facilities will boost extension services, and may lead to the reward received by the workers due to the quality services provided.
\end{abstract}

Keywords: performance of extension workers, non-technical training, district extension agency (BP4K), learning plan.

\section{Abstrak}

Guna mendukung kinerja penyuluh pertanian BP4K Kabupaten Bungo mengadakan pelatihan non-teknis. Penelitian ini bertujuan untuk: menganalisis kesesuaian pelatihan bagi penyuluh pertanian serta menganalisis kinerja penyuluh pertanian setelah berpartisipasi dalam pelatihan non-teknis. Penelitian dilakukan dengan cara sensus pada 100 responden dan analisis data menggunakan statistik deskriptif dan statistik inferensial (multiple linear regresi). Hasil penelitian menunjukkan bahwa: 1) frekuensi pelatihan dan motivasi dari penyuluh pertanian positif mempengaruhi kinerja penyuluh; 2) Metode pelatihan dan infrastruktur mempengaruhi efektivitas pelatihan. Metode yang lebih inovatif dalam pelatihan dengan didukung oleh infrastruktur yang lebih baik akan meningkatkan kinerja yang lebih baik dari penyuluh; 3) kesesuaian materi pelatihan dan rencana pembelajaran yang lebih baik akan mempengaruhi penyuluh dalam meningkatkan kinerja pelatihan; 4) dukungan fasilitas dari organisasi penyuluhan akan meningkatkan kinerja penyuluh, dan penyuluh pertanian menerima reward/imbalan atas kinerja mereka.

Kata kunci: kinerja penyuluh, pelatihan non-teknis, lembaga penyuluhan kabupaten (BP4K), rencana pembelajaran.

\section{Pendahuluan}

Kinerja penyuluh pertanian yang memenuhi standar penugasan sangat diperlukan untuk mencapai tujuan pembangunan pertanian. Kinerja penyuluh pertanian merupakan hasil kerja yang dicapai sesuai tugas dan tanggung jawab yang dilaksanakan secara efektif dan efisien berdasarkan kemampuan, pengalaman serta penggunaan waktu (Herbenu, 2007).

Kondisi penyuluhan pertanian yang terus mengalami perubahan baik sejak pemerintahan orde lama, orde baru sampai orde reformasi turut mempengaruhi citra penyuluhan pertanian dan kinerja dari penyuluh. Kinerja penyuluh pertanian Kabupaten Bungo semenjak kegiatan penyuluhan dikembalikan ke daerah semakin menurun dan cenderung tidak adanya regenerasi penyuluh yang memiliki kompetensi yang memadai hal ini berdasarkan informasi dari Kepala bidang (Kabid) Pengembangan Sumberdaya Manusia BP4K Kabupaten Bungo. Hal ini disebabkan semenjak diberlakukannya otonomi daerah terjadi perubahan-perubahan pada kelembagaan penyuluhan sehingga ada perubahan yang mendasar terhadap pembinaan penyuluhan pertanian. Salah satu penyebab turunnya kinerja 
penyuluh adalah adanya ketidaksesuaian antara tingkat kemampuan yang dimiliki oleh para penyuluh dengan perkembangan kebutuhan dan dinamika permasalahan yang dihadapi oleh penyuluh pada masyarakat sasaran di lapangan. Salah satu faktor yang mempengaruhi adalah kurangnya perhatian instansi dalam memberikan pelatihan sesuai kebutuhan (Turere, 2013).

Peningkatan pengetahuan, keterampilan, perubahan sikap, serta hal-hal yang dapat menjadi perbaikan terhadap peningkatan kinerja dan produktivitas dalam memberdayakan petani dapat dilaksanakan melalui pelatihan-pelatihan. Lembaga penyuluhan untuk meningkatkan kinerja melakukan berbagai cara salahsatunya kursus dan pelatihan. Sapar et al., (2011) dan Hamzah (2011) menemukan bahwa terdapat hubungan signifikan antara sejumlah karakteristik penyuluh seperti umur, masa kerja, motivasi kerja serta pelatihan dan kompetensi dengan kinerja penyuluh pertanian. Hal ini menunjukkan bahwa karakteristik penyuluh serta pelatihan merupakan unsur penting yang dapat mempengaruhi kinerja dari seorang penyuluh.

Pelatihan di BP4K (Badan Pelaksana Penyuluh Pertanian, Perikanan dan Kehutanan) Kabupaten Bungo telah dilaksanakan sejak tahun 2011 guna meningkatkan kinerja di wilayah kerja BP4K Kabupaten Bungo. Dalam kurun waktu 20112014 telah dilaksanakan sebanyak 96 kali pelatihan baik teknis maupun non teknis. Pelatihan non teknis yang dilaksanakan bertujuan untuk mengembangkan kapasitas dan pengetahuan penyuluh di BP4K Kabupaten Bungo. Tujuan utama dari penelitian ini adalah: menganalisis kesesuaian pelatihan yang diberikan berdasarkan karakteristik peserta, kurikulum pelatihan, kompetensi pelatih penyuluhan dan dukungan kelembagaan dari BP4K Bungo serta menganalisis kinerja penyuluh pertanian $\mathrm{BP} 4 \mathrm{~K}$ Bungo setelah mengikuti pelatihan non-teknis.

\section{Metode Penelitian}

Penelitian dilakukan menggunakan metode sensus dengan menggunakan pendekatan kuantitatif sebagai tumpuan analisis dengan penjelasan secara deskriptif dan kualitatif guna memperoleh informasi sehingga dapat mendukung dan memberi makna data kuantitatif, yakni melalui cara pengamatan dan wawancara semi terstrukur melalui informan yakni Kepala BP4K, Kepala BP3K, serta pengurus.. Responden penelitian ini adalah semua penyuluh pertanian di Kabupaten Bungo, Provinsi Jambi yang pernah mengikuti pelatihan peningkatan SDM Penyuluh di BP4K (100 penyuluh). Lokasi penelitian dilaksanakan di BP4K Kabupaten Bungo. Pemilihan daerah ini dilakukan secara sengaja (purposive) di Kabupaten Bungo dengan mengambil 17 BP3K yang tersebar di Kabupaten Bungo. Pengambilan data dilakukan mulai Mei sampai Juli 2015.

Data primer yang dikumpulkan yaitu karakteristik penyuluh, tingkat kesesuaian kurikulum dengan kebutuhan pelatihan, tingkat kompetensi penyuluh dan dukungan lembaga penyuluhan, sedangkan variabel terikat adalah Kinerja Penyuluh. Data sekunder diperoleh dari dokumen-dokumen yang berhubungan dengan lingkup penelitian. Sumber-sumber tersebut antara lain adalah profil Kabupaten yang menjadi lokasi penelitian, perkembangan materi pelatihan serta laporan pelaksanaan pelatihan yang menunjang penelitian. Data dianalisis dengan uji regresi linear berganda. Syarat data untuk melakukan uji statistik regresi linear berganda adalah data dengan skala rasio atau skala inteval. Oleh sebab itu data ordinal yang diperoleh perlu dilakukan transformasi data terlebih dahulu ke dalam bentuk indeks (Sumardjo 1999).

\section{Hasil dan Pembahasan}

\section{Karakteristik Penyuluh Peserta Pelatihan}

Karakteristik individu merupakan perbedaan antara individu yang satu dengan individu yang lainnya. Karakteristik penyuluh peserta pelatihan meliputi umur, pendidikan formal, jenis kelamin, masa kerja, jumlah pelatihan yang pernah diikuti, dan motivasi mengikuti pelatihan

Penyuluh peserta pelatihan masih tergolong penyuluh muda (27-37 tahun). Mayoritas penyuluh di BP4K Kabupaten Bungo adalah laki-laki padahal dilapangan penyuluh wanita juga dibutuhkan guna memberikan penyuluhan tentang kelompok wanita tani ataupun Dasawisma. Adapun jumlah pelatihan yang diikuti pertahun adalah 11-20 kali pelatihan dengan rata-rata pelatihan yang dikuti sebanyak 
Tabel 1 Persentase penyuluh peserta pelatihan menurut karakteristik individu

\begin{tabular}{|c|c|c|}
\hline Karakteristik Penyuluh & Kategori & Persentase $(\%)(n=100)$ \\
\hline \multirow[t]{3}{*}{ Umur (Tahun) } & Muda (27-37) & 46 \\
\hline & Dewasa (38-48) & 27 \\
\hline & Tua $(>48)$ & 27 \\
\hline \multirow[t]{3}{*}{ Pendidikan formal } & SMA & 17 \\
\hline & DIII & 18 \\
\hline & $\mathrm{DIV} / \mathrm{S} 1-\mathrm{S} 2$ & 65 \\
\hline \multirow[t]{2}{*}{ Jenis kelamin } & Laki-laki & 72 \\
\hline & Perempuan & 28 \\
\hline \multirow{3}{*}{ Masa kerja (Tahun) $(\bar{X}=13,74$ Tahun $)$} & Rendah (4-14) & 68 \\
\hline & Sedang (15-25) & 12 \\
\hline & Tinggi $(>25)$ & 20 \\
\hline \multirow{3}{*}{$\begin{array}{l}\text { Jumlah pelatihan yang diikuti (Kali) } \bar{X}=16,43 \\
\text { Kali) }\end{array}$} & Rendah (1-10) & 26 \\
\hline & Sedang (11-20) & 46 \\
\hline & Tinggi $(>20)$ & 28 \\
\hline \multirow{3}{*}{ Motivasi mengikuti pelatihan $(\bar{X}=9,89)$} & Rendah (skor 4-7) & 8 \\
\hline & Sedang (skor 8-11) & 64 \\
\hline & Tinggi (skor > 11) & 28 \\
\hline
\end{tabular}

16 kali, sedangkan motivasi dari penyuluh dalam mengikuti pelatihan adalah berasal dari keinginan sendiri guna mengembangkan keterampilan dan meningkatkan pengetahuan. Pendidikan formal ratarata adalah DIV/S1, menurut Soekartawi (2005) dan Slamet (2003) semakin tinggi pendidikan seseorang, semakin tinggi pula pengetahuan, sikap dan keterampilan, dan efisien bekerja serta semakin mengetahui teknik bekerja yang lebih menguntungkan.

\section{Persepsi Penyuluh Peserta Pelatihan terhadap Kesesuaian Kurikulum Pelatihan, Kompetensi Pelatih, dan Dukungan Lembaga Penyuluhan dalam Pelatihan non-Teknis}

Kesesuaian kurikulum pelatihan, kompetensi pelatih, dan dukungan lembaga penyuluhan merupakan tiga hal utama yang dapat berkontribusi dalam kegiatan pelatihan non-teknis. Tabel 2 menunjukkan persepsi penyuluh peserta pelatihan terhadap tiga indikator tersebut.

Tingkat kesesuaian kurikulum pelatihan cenderung tinggi. Hal ini dilihat dari aspek metode pelatihan serta sarana dan prasarana pelatihan yang dinilai baik oleh responden. Namun pelatihan belum direncanakan secara baik serta materi pelatihan yang masih kurang sesuai dengan kebutuhan penyuluh peserta pelatihan.

Proses pelatihan yang dipersiapkan dan direncanakan dengan baik sesuai dengan kebutuhan akan dirasakan manfaat dari pelatihan tersebut. Indrianingsih (2011) dan Roswida (2003) 
Tabel 2 Kategori dan persentase kesesuaian kurikulum pelatihan, kompetensi pelatih, dan dukungan lembaga penyuluhan

\begin{tabular}{|c|c|c|c|}
\hline \multirow[t]{2}{*}{ Indikator } & \multicolumn{3}{|c|}{ Kategori } \\
\hline & Rendah & Sedang & Tinggi \\
\hline \multicolumn{4}{|l|}{ 1. Kesesuaian Kurikulum Pelatihan } \\
\hline Perencanaan pelatihan & 36 & 33 & 31 \\
\hline Materi pelatihan & 27 & 42 & 31 \\
\hline Metode pelatihan & 11 & 2 & 87 \\
\hline $\begin{array}{l}\text { Sarana dan prasarana } \\
\text { pelatihan }\end{array}$ & 11 & 24 & 65 \\
\hline \multicolumn{4}{|l|}{ 2. Kompetensi Pelatih } \\
\hline $\begin{array}{l}\text { Penguasaan substansi } \\
\text { materi }\end{array}$ & 0 & 10 & 90 \\
\hline $\begin{array}{l}\text { Kemampuan merencanakan } \\
\text { pembelajaran }\end{array}$ & 0 & 3 & 97 \\
\hline $\begin{array}{l}\text { Kemampuan melaksanakan } \\
\text { pembelajaran }\end{array}$ & 14 & 86 & 0 \\
\hline $\begin{array}{l}\text { Kemampuan dalam } \\
\text { mengevaluasi pembelajaran }\end{array}$ & 56 & 44 & 0 \\
\hline \multicolumn{4}{|l|}{ 3. Dukungan Lembaga Penyuluhan } \\
\hline Fasilitas & 0 & 10 & 90 \\
\hline Insentif/Penghargaan & 0 & 3 & 97 \\
\hline
\end{tabular}

menyatakan materi, metode dan sarana prasarana pelatihan yang dikomunikasikan harus inovatif dan melibatkan peserta dalam kegiatan pelatihan.

Tingkat kompetensi penyuluh pelatih cenderung sedang dalam menguasai aspek-aspek dalam kegiatan pelatihan. Aspek yang tergolong baik adalah aspek penguasaan substansi materi serta kemampuan merencanakan pembelajaran oleh penyuluh pelatih. Penyuluh pelatih telah menguasai substansi materi yang diberikan kepada peserta. Selain itu penyuluh pelatih juga mengikuti pelatihan guna meningkatkan keterampilan serta pengetahuan dan telah berpengalaman di bidangnya. Kompetensi dibidang perencanaan pembelajaran dimaksud meliputi kemampuan dalam menyusun rencana pembelajaran, modul pembelajaran, evaluasi pembelajaran, dan bahan presentasi penyajian materi Penyuluh pelatih dalam pelaksanaan pembelajaran sebagian besar lebih fokus kepada materi yang mereka sampaikan sehingga tidak terjadi komunikasi yang efektif dan kurangnya semangat dari penyuluh peserta pelatihan dalam mengikuti kegiatan pembelajaran dalam pelatihan. Namun, pada umumnya tidak ada dilakukan evaluasi. Evaluasi yang dilaksanakan hanya berupa catatan-catatan pelatihan serta apa saja kendala dari pelatihan yang dilaksanakan. Alasannya karena analisis hasil evaluasi tidak pernah dituntut oleh penyelenggara pelatihan (BP4K). Penyuluh pelatih menyerahkan tabulasi hasil evaluasi. Sehingga penyuluh pelatih kurang tertantang untuk mengembangkan kompetensinya dalam pelaksanaan evaluasi pembelajaran.

Dukungan lembaga penyuluhan merupakan hal-hal yang diberikan oleh pihak lembaga penyuluhan yang berguna untuk membantu serta memfasilitasi penyuluh agar mempermudah penyuluh untuk melaksanakan tugas di lapangan. Hal ini juga dapat menjadi salah satu hal untuk meningkatkan kinerja penyuluh pertanian. Salah satu dukungan lembaga adalah dengan memberikan fasilitas kendaraan roda dua kepada seluruh penyuluh, kendaraan roda empat untuk koordinator penyuluh, laptop bagi penyuluh yang berprestasi, 
serta sarana prasarana lainnya. Adanya pemberian fasilitas tersebut memudahkan kegiatan penyuluh dalam melaksanakan kegiatan penyuluhan serta mengunjungi wilayah kerja penyuluh tersebut. Sistem penghargaan berkaitan dengan bagaimana organisasi memberikan pengakuan dan imbalan kepada penyuluh dalam rangka menjaga keselarasan antara kebutuhan individu dan tujuan organisasi. Bagi penyuluh sistem penghargaan menumbuhkan motivasi dan semangat kerja serta kepuasan kerja. Insentif atau penghargaan yang diberikan bukan saja semata-mata berupa materi tetapi juga berupa pemberian izin serta sarana prasarana guna mendukung kegiatan penyuluh dilapangan. Selain itu hubungan yang baik antara sesama penyuluh serta antusiasme dari petani atau masyarakat diwilayah kerja menjadi penghargaan tersendiri bagi penyuluh sehingga dapat menjadi semangat bagi penyuluh untuk meningkatkan kinerja mereka. Hal ini sesuai pendapat dengan Sudarmanto (2009) yang menyatakan bahwa faktor yang mempengaruhi kinerja individu diantaranya adalah sistem penghargaan (reward system). Oleh karena itu penataan sistem penghargaan dalam bentuk materi maupun non materi sangat penting menjadi salah satu prioritas $\mathrm{BP} 4 \mathrm{~K}$.

\section{Kinerja Penyuluh Pertanian}

Kinerja adalah hasil kerja yang dapat dicapai oleh seseorang atau sekelompok orang dalam suatu organisasi sesuai dengan wewenang dan tanggung jawab masing-masing ke arah pencapaian tujuan yang ditetapkan (Hasibuan, 2001). Indikator kinerja dalam penelitian ini berdasarkan Peraturan Menteri Nomor 91 Tahun 2013 tentang penilaian kinerja (Tabel 3).
Tersedianya dokumen tentang persiapan kegiatan penyuluhan pertanian adalah hasil pekerjaan penyuluh pertanian dalam mempersiapkan kegiatan penyuluhan pertanian. Sebagian besar penyuluh pertanian sudah memahami dan melaksanakan kegiatan-kegiatan dari tahapan ini. Hal ini dikuatkan oleh pernyataan Kepala Sub Bidang Sumber Daya Manusia (Kasubbid SDM) BP4K Kabupaten Bungo menyatakan bahwa semua penyuluh pertanian setiap tahun membuat rencana kerja tahunan, membuat programa penyuluhan, membuat peta monografi dan potensi wilayah binaan penyuluh. hal tersebut dapat dilihat dan dibuktikan dari bukti dokumen resmi pengajuan angka kredit kegiatan-kegiatan persiapan penyuluhan yang telah didokumentasikan dan dinilai serta disahkan oleh atasan atau koordinator wilayah penyuluh. Secara umum kegiatan pada tahapan ini telah dilakukan dengan baik oleh sebagian besar responden penyuluh.

Tingkat pelaksanaan penyuluhan dilihat dalam penyusunan materi penyuluhan desiminasi materi penyuluhan, penerapan metode penyuluhan, pengembangan kapasitas, kualitas serta kuantitas kelompok sasaran atau binaan. Berbagai kegiatan responden pada tahapan ini sebagian besar telah dilakukan dengan baik serta ada sebagian yang masih kurang baik. Beberapa kegiatan yang sudah baik dilakukan oleh penyuluh yaitu: rutin melakukan diseminasi materi penyuluhan dengan melaksanakan pertemuan dengan masyarakat sasaran, penerapan metode penyuluhan seperti kunjungan/tatap muka kepada anggota kelompok tani binaan.

Kontinuitas monitoring dan evaluasi kegiatan penyuluhan pertanian dalam penelitian ini adalah hasil pekerjaan penyuluh pertanian dalam melaksanakan pemantauan, penilaian dan pelaporan kegiatan penyuluhan pertanian. Ada beberapa faktor

Tabel 3 Tingkat kinerja penyuluh pertanian di Kabupaten Bungo

\begin{tabular}{lccc}
\hline Dukungan lembaga penyuluhan & \multicolumn{2}{c}{ Kategori } \\
& Rendah & Sedang & Tinggi \\
\hline $\begin{array}{l}\text { Ketersediaan dokumen persiapan kegiatan penyu- } \\
\text { luhan pertanian }\end{array}$ & $(6,00) 6$ & $(37,00) 37$ & $(57,00) 57$ \\
Tingkat Pelaksanaan Penyuluhan & 0 & & \\
Kontinuitas Evaluasi dan Pelaporan & 0 & $(3,00) 93$ & $(7,00) 7$ \\
\hline
\end{tabular}

Ket: $\mathrm{n}=100$, ( ): Responden dalam persen 
yang menyebabkan kinerja responden penyuluh cukup baik pada tahap ini. Pertama, adanya pertemuan rutin setiap awal bulan sekaligus pelatihan di BP3K unit kerja masing-masing penyuluh mengevaluasi pekerjaan penyuluh. Kegiatan tersebut langsung dipimpin oleh kepala BP3K dan Kepala Dinas BP4K atau yang mewakili beserta seluruh penyuluh koordinator wilayah. Kedua, adanya kegiatan pertemuan pemantauan, evaluasi lainnya yang dilakukan pada setiap pertengahan bulan yang hanya dihadiri oleh sesama rekan penyuluh beserta semua kordinator wilayah penyuluhan.

\section{Pengaruh Karakteristik Penyuluh Peserta Pelatihan terhadap Kinerja Penyuluh Pertanian}

Beberapa karakteristik penyuluh seperti: Umur, pendidikan formal, masa kerja, jumlah pelatihan yang pernah diikuti serta motivasi mengikuti pelatihan yang mempengaruhi kinerja penyuluh pertanian adalah jumlah pelatihan dan motivasi mengikuti pelatihan (Tabel 4).

Aspek yang mempengaruhi karakteristik penyuluh adalah jumlah pelatihan yang diikuti dan motivasi dari penyuluh dalam mengikuti pelatihan. Artinya semakin banyak jumlah pelatihan yang diikuti oleh penyuluh pertanian maka semakin banyak pengetahuan serta keterampilan yang didapatkan oleh penyuluh dalam meningkatkan kinerja, sehingga bermanfaat bagi penyuluh untuk digunakan di wilayah kerja serta dapat meningkatkan kinerja penyuluh pertanian. Motivasi dari penyuluh dalam mengikuti pelatihan berpengaruh nyata terhadap karakteristik penyuluh peserta dan positif

Tabel 4 Pengaruh karakteristik penyuluh

peserta pelatihan terhadap

kinerja penyuluh

\begin{tabular}{lc}
\hline Peubah/Indikator & $\begin{array}{c}\text { Koefisien regresi } \\
\text { (b) }\end{array}$ \\
\hline Umur & 0,193 \\
Pendidikan Formal & 0,063 \\
Masa Kerja & 0,296 \\
Jumlah Pelatihan yang Pernah & $0,262^{*}$ \\
diikuti & $0,705^{*}$ \\
Motivasi Mengikuti Pelatihan & \\
\hline
\end{tabular}

*Signifikan pada $\alpha=0,05$ terhadap kinerja penyuluh pertanian. Semakin tinggi motivasi penyuluh responden dalam mengikuti pelatihan maka kinerja penyuluh akan semakin tinggi. Motivasi responden mengikuti pelatihan dilatarbelakangi oleh dorongan untuk mendapatkan pengetahuan dan keterampilan guna peningkatan kinerja mereka selain hal tersebut adanya kewajiban dan dorongan dari atasan membuat penyuluh bersemangat untuk mengikuti kegiatan pelatihan yang diadakan. Hal ini memperkuat hasil penelitian Sapar et al., (2011) dimana pelatihan berhubungan nyata dengan kinerja penyuluh pertanian.

\section{Pengaruh Tingkat Kesesuaian Kurikulum Pelatihan terhadap Kinerja Penyuluh Pertanian}

Kesesuaian kurikulum berpengaruh terhadap kinerja penyuluh pertanian dalam hal kesesuaian Metode pelatihan dan sarana serta prasarana pengaruh ini bernilai positif artinya kinerja meningkat jika metode dan sarana serta prasaran sesuai. Beberapa Metode seperti role playing, diskusi, studi kasus, rapat terbukti efektif untuk meningkatkan kinerja karena dapat diterapkan saat penyuluh pertanian melaksanakan kegiatan di wilayah kerja. Semakin tinggi kesesuaian metode pelatihan yang digunakan dalam proses pembelajaran maka semakin mudah penyuluh dalam mengikuti kegiatan pelatihan tersebut sehingga dapat meningkatkan kinerja penyuluh pertanian. (Tabel 5).

Pada proses kegiatan pembelajaran sarana dan prasarana yang tersedia seperti ruang kelas, ketersediaan listrik, serta peralatan kelas sudah cukup memadai. Sedangkan LCD, proyektor, laptop, dibawa langsung oleh penyuluh pelatih.

Tabel 5 Pengaruh tingkat kesesuaian kurikulum pelatihan terhadap kinerja penyuluh

\begin{tabular}{lc}
\hline Peubah/Indikator & $\begin{array}{c}\text { Koefisien regresi } \\
\text { (b) }\end{array}$ \\
\hline Perencanaan Pelatihan & $-0,001$ \\
Materi Pelatihan & 0,080 \\
Metode Pelatihan & $0,147^{*}$ \\
Sarana dan Prasarana Pelatihan & $0,147^{*}$ \\
\hline
\end{tabular}

*Signifikan pada $\alpha=0,05$ 
Tabel 6 Pengaruh tingkat kompetensi penyuluh pelatih terhadap kinerja penyuluh

\begin{tabular}{ll}
\hline Peubah/Indikator & Koefisien regresi (b) \\
\hline Penguasaan Substansi Materi & $* 0,291$ \\
Kemampuan Merencanakan Pembelajaran & $* 0,293$ \\
Kemampuan Melaksanakan Pembelajaran & 0,150 \\
Kemampuan dalam Mengevaluasi Pembelajaran & 0,164 \\
\hline
\end{tabular}

Signifikan pada $\alpha=0,05$

\section{Pengaruh Tingkat Kompetensi Penyuluh Pelatih terhadap Kinerja Penyuluh Pertanian}

Tingkat kompetensi penyuluh pelatih pada penguasaan substansi materi berpengaruh nyata dan positif terhadap kinerja penyuluh pertanian. Semakin tinggi kompetensi penyuluh pelatih dalam kegiatan pembelajaran pelatihan maka semakin bermanfaat untuk peningkatan kinerja penyuluh. Substansi materi yang baik menurut Saylor (2006) harus memenuhi beberapa aspek yaitu adanya relevansi terhadap sasaran kegiatan, kesesuaian materi, materi dengan kegunaan (Tabel 6).

Kompetensi Kemampuan penyuluh pelatih dalam merencanakan pembelajaran pada saat kegiatan pelatihan berpengaruh nyata dan positif dalam peningkatan kinerja penyuluh pertanian. Semakin baik penyuluh pelatih merencanakan pembelajaran pada kegiatan pelatihan maka semakin mudah penyuluh peserta pelatihan dalam mengikuti pelatihan serta mengambil manfaat dari kegiatan pelatihan tersebut sehingga bermanfaat untuk meningkatkan kinerja peserta penyuluh pertanian. Kemampuan penyuluh pelatih dalam melaksanakan pembelajaran pada saat kegiatan pelatihan harus selalu ditingkatkan. Warisdiono (2012) menyatakan bahwa kemampuan merencanakan pembelajaran dapat juga ditingkatkan dengan cara saling berbagi pengalaman antar pelatih.

\section{Pengaruh Dukungan Lembaga Penyuluhan terhadap Kinerja Penyuluh Pertanian}

Dukunganlembagapenyuluhan memengaruhi kinerja penyuluh pertanian (Tabel 7). Fasilitas dari lembaga penyuluhan berpengaruh nyata positif terhadap peningkatan kinerja penyuluhan pertanian artinya, semakin besar dukungan fasilitas seperti tersedianya sarana dan prasarana serta hal-hal yang diperlukan untuk menunjang kegiatan penyuluhan dilapangan maka semakin meningkat kinerja penyuluh pertanian. Insentif atau penghargaan berpengaruh nyata dan positif terhadap kinerja penyuluh pertanian. Semakin tinggi insentif atau penghargaan yang diberikan oleh lembaga penyuluhan maka semakin tinggi kinerja penyuluh pertanian. Insentif atau penghargaan yang diberikan oleh lembaga penyuluhan bukan hanya berupa imbalan dalam bentuk gaji dan honor saja, namun pemberian izin serta penghargaan jika penyuluh berprestasi. Firmansyah (2013) menyatakan bahwa salah satu dukungan lembaga penyuluhan yang dapat diberikan kepada penyuluh agar memudahkannya untuk bekerja adalah memberikan fasilitas kendaraan dan Laelani dan Jahi (2006) menyatakan bahwa pemberian insentif berhubungan dengan kinerja dan mempengaruhi kinerja penyuluh pertanian.

\section{Kesimpulan}

Tabel 7 Pengaruh dukungan lembaga penyuluhan terhadap kinerja penyuluh

\begin{tabular}{lc}
\hline \multicolumn{1}{c}{ Peubah/Indikator } & Koefisien regresi $(\mathbf{b})$ \\
\hline Fasilitas & $* 0,149$ \\
Insentif/ & $* 0,070$ \\
Penghargaan &
\end{tabular}

Tingkat kinerja penyuluh peserta pelatihan non teknis di BP4K kabupaten Bungo masih belum optimal terutama dalam pelaksanaan serta evaluasi dan pelaporan secara kontinu. Meskipun dalam menyediakan dokumen-dokumen persiapan kegiatan penyuluhan pertanian cukup lengkap. Pelaksanaan pelatihan non teknis yang diselenggarakan terbukti mempengaruhi kinerja penyuluh. Adapun aspek- 
aspek yang mempengaruhi hal tersebut dalam hal kesesuaian kurikulum adalah metode dan ketersediaan sarana serta prasarana pelatihan, kemampuan penyuluh pelatih dalam menguasai substansi materi pembelajaran serta kemampuan dalam merencanakan pembelajaran baik di kelas ataupun saat diadakan praktek, dukungan lembaga BP4K berupa fasilitas, insentif/ penghargaan, serta karakteristik penyuluh peserta pelatihan yakni jumlah pelatihan dan motivasi mengikuti pelatihan.

\section{Daftar Pustaka}

Firmansyah. 2013. Motivasi, Kepuasan Kerja, dan Kinerja Penyuluh Kehutanan di Kabupaten Cianjur Jawa Barat. Jurnal Penyuluhan. 11(1): 11-22.

Hamzah I. 2011. Faktor Penentu Kinerja Penyuluh Pertanian di Kota Tidore Kepulauan Provinsi Maluku Utara. Tesis. Bogor (ID): Institut Pertanian Bogor.

Hasibuan M. 2001. Manajemen Sumber Daya Manusia: Pengertian Dasar, Pengertian, dan Masalah. Jakarta: PT. Toko Gunung Agung.

Herbenu PC. 2007. Pengembangan Sumberdaya Petugas Penyuluh Lapangan PPL Pertanian Guna Menghadapi Persaingan dan Meraih Peluang Kerja. Jurnal Ilmu-Ilmu Pertanian. 3(1):1-11.

Indrianingsih KS. 2011. Pedoman Pembinaan Program Pestisida. [internet http://deptan.go.id]. Laelani A dan Jahi A. 2006. Kinerja Penyuluh Pertanian di Beberapa Kabupaten di Provinsi Jawa Barat. Jurnal Penyuluhan. 2(2):99-106

Roswida R. 2003. Tahapan proses keputusan adopsi inovasi pengendalian hama dan penyakit tanaman dengan agen hayati (Kasus petani sayuran di Kecamatan Sungai Puar Kabupaten Agam Sumatera Barat). Tesis. Bogor (ID): Institut Pertanian Bogor

Sapar, Jahi A, Asngari PS, Saleh A, Purnaba IGP. 2011. Faktor-faktor yang berpengaruh pada kinerja penyuluh pertanian dan dampaknya pada kompetensi petani kakao di empat wilayah di Sulawesi Selatan. Forum Pascasarjana. 34(4):297-305.

Saylor, Gallen, William, Alexander. 2006. Curriculum Planning for Training. New York (US): Halt Reineheart\&Winston, Inc.
Siregar AN dan Saridewi TR. 2010. Hubungan Antara Motivasi Dan Budaya Kerja Dengan Kinerja Penyuluh Pertanian Di Kabupaten Subang, Provinsi Jawa Barat. Jurnal Penyuluhan Pertanian. 5(1): 24-35.

Slamet M. 2003. Membentuk Pola Perilaku Manusia Pembangunan. Disunting oleh Ida Yustina dan Adjat Sudradjat. Bogor (ID): Institut Pertanian Bogor.

Soekartawi. 2005. Prinsip Dasar Komunikasi Pertanian. Jakarta (ID): Universitas Indonesia.

Sudarmanto. 2009. Kinerja dan Pengembangan Kompetensi SDM (Teori, Dimensi Pengukuran dan Implementasi dalam Organisasi). Yogyakarta (ID): Pustaka Pelajar.

Sumardjo. 1999. Transformasi Model Penyuluhan Pertanian Menuju Pengembangan Kemandirian Petani: Kasus di Propinsi Jawa Barat. Disertasi. Bogor (ID): Institut Pertanian Bogor.

Turere VN. 2013. Pengaruh Pendidikan dan Pelatihan Terhadap Peningkatan Kinerja Karyawan pada Balai Pelatihan Teknis Pertanian Kalasey. Jurnal EMBA. 1(3):10-19[diunduh 2 Januari 2015].

Warisdiono E, Sarma M, Gani MD, Susanto D. 2012. Kompetensi dan Kinerja Fasilitator Pelatihan Pusat Pengembangan dan Pemberdayaan Pendidik dan Tenaga Kependidikan Pertanian (P4TK Pertanian), Kementerian Pendidikan dan Kebudayaan. Jurnal Penyuluhan. 9(2): 111-119. 